\title{
ДОСВІД ХІРУРГТЧНОГО ЛІКУВАННЯ РОЗРИВУ СТРАВОХОДУ РІЗНОЇ ЛОКАЛІЗАЦІЇ
}

\author{
П. П. Шипулін, В. І. Байдан, О. Ю. Троніна, А. Аграхарі, Б. Ю. Брайловський, М. Ю. Целіков, \\ В. Є. Севергін, О. М. Козяр, В. В. Байдан, О. О. Кирилюк, С. В. Агеєв, М. Ю. Голубенко
}

Одеська обласна клінічна лікарня

\section{EXPERIENCE OF SURGICAL TREATMENT OF ESOPHAGEAL RUPTURE OF VARIOUS LOCALIZATION}

\author{
P. P. Shypulin, V. I. Baydan, O. Yu. Tronina, A. Agrakhari, B. Yu. Braylovskyi, M. Yu. Tselikov, \\ V. E. Severgin, O. M. Kozyar, V. V. Baydan, O. O. Kyrylyuk, S. V. Ageyev, M. Yu. Golubenko \\ Odessa Regional Clinical Hospital
}

\begin{abstract}
Рефрерат
Узагальнений досвід лікування 61 потерпілого з приводу розриву стравоходу (РС) різної етіології. Наведена хірургічна тактика залежно від рівня перфорації. Доведена необхідність накладання первинного шва стравоходу незалежно від строків 3 моменту РС, доцільність тимчасового виключення стравоходу. Померли 14 (22,9\%) хворих. Найгірші результати відзначені при спонтанному розриві нижньої третини стравоходу (летальність 18\%). Встановлена перспективність застосування мініінвазивних технологій в лікуванні хворих з приводу РС.

Ключові слова: розрив стравоходу; зашивання розриву стравоходу; лігування розриву стравоходу.

Abstract

Experience of treatment of 61 injured persons for esophageal rupture of various etiology was summarized. Surgical tactics, depending on the perforation level, was adduced. Necessity of the primary esophageal suturing, not depending on terms of the rupture occurrence was proved, and expediency of performing temporary exclusion of the esophagus as well. In total $14(22.9 \%)$ patients died. Poorest results were noted in spontaneous rupture of the esophageal in lower third (lethality 18\%). Perspective of application of miniinvasive technologies in treatment of patients, suffering esophageal rupture, is stressed.

Keywords: rupture of the esophagus; suturing of esophageal rupture; ligation of esophageal rupture.
\end{abstract}

Лікування РС - складна хірургічна проблема. Незважаючи на відносно сприятливі результати, досягнуті в окремих спеціалізованих центрах [1 - 4], своєчасна діагностика РС і раціональна хірургічна тактика часто спричиняють значні труднощі у хірургів.

\section{МАТЕРІАЛИ I МЕТОДИ ДОСЛІДЖЕННЯ}

У клініці лікували 61 потерпілого 3 приводу РС віком від 13 до 78 років. Чоловіків було 50, жінок - 11 . Найбільш частими причинами РС були пошкодження стравоходу під час бужування, дилатації та видалення сторонніх тіл. У 17 хворих виник спонтанний РС, який в літературі називають «синдром Боерхаве». В одного хворого РС виник під час діагностичної гастрофіброскопіі, в одного - пошкодження спричинене провідником ендотрахеальної трубки під час інтубації трахеї. У 2 пацієнтів виявлена перфорація гігантського дивертикулу стравоходу з розривом його стінки, у 2 - причиною РС була травма шийного відділу хребта і закрита травма грудей. В одного пацієнта травма шийної частини стравоходу зумовлена металевою шпицею під час остеосинтезу ключиці.

У більшості пацієнтів РС діагностований у строки більше 1 доби, у $21 \%$ хворих - пізніше ніж через 3 доби.

РС в шийній ділянці відзначений у $23(37,7 \%)$ хворих, у середній третині - у 13 (21,3\%), нижній третині - у 25 (41,0\%).

В діагностичний комплекс обов'язково включали рентгенологічне дослідження органів грудної порожнини та стравоходу з використанням водорозчинної контрастної речовини. В останні роки вважаємо обов'язковим проведення комп'ютерної томографії шиї, грудної і черевної порожнин 3 контрастуванням стравоходу. Ендоскопічне дослідження здійснювали при РС, що виник під час видалення сторонніх тіл або балоної дилатації стриктури стравоходу під контролем гастрофіброскопії.

Як правило, зазначений діагностичний комплекс був достатнім для виявлення РС, його локалізації та поширення гнійного процесу на навколишні тканини. Хірургічна тактика, використана нами при РС, суттєво не різнилася від наведеної нами раніше [5, 6].

Операційний доступ обирали залежно від локалізації РС. При пошкодженні шийної і верхньогрудної частин стравоходу виконували шийну медіастинотомію на боці травми. За поширеної флегмони шиї і медіастиніту шийний доступ застосовували 3 обох боків з об'єднанням обох гнійних порожнин в єдину, тупо обходячи стравохід ззаду. Дефект стравоходу намагалися зашити незалежно від строків його перфорації. Операцію завершували проточно-аспіраційним дренуванням клітковинних просторів шиї і середостіння. Для харчування пацієнту встановлювали назогастральний зонд, рідше - накладали гастростому.

При РС в середній третині виконували правобічну торакотомію у п'ятому міжребер'і. Після широкої медіастинотомії і виявлення РС його також зашивали. При цьому ча- 
сто дефект слизової оболонки стравоходу перевищував за довжиною зовнішню рану. В подібних ситуаціях виконували поздовжню міотомію в межах дефекту слизової оболонки і тільки потім роздільно зашивали слизову і м'язову оболонку за допомогою двохрядного шва. Операцію завершували проточноаспіраційним дренуванням середостіння і плевральної порожнини, а також лапаротомією з накладанням гастростоми. Рідше, крім зашивання, виключали стравохід за Погодиною [7] шляхом його лігування синтетичними вікриловими нитками, що розсмоктуються.

За нижньогрудної локалізації РС використовували трансторакальний доступ по сьомому міжребер'ю. Після медіастинотомії на дефект стравоходу накладали двохрядний шов за наведеною методикою. За виражених некротичних змін накладали однорядний шов через всі оболонки на товстому зонді. За такої ситуації шов використовували лише для тимчасової герметизації стравоходу. Обов'язковим вважали тимчасове виключення стравоходу вище і нижче зони дефекту шляхом його лігування вікриловими нитками. Якщо дозволяв стан хворого, здійснювали фундоплікацію зони дефекту шляхом виведення передньої стінки шлунка в плевральну порожнину через невеликий розріз діафрагми.

Операцію завершували дренуванням плевральної порожнини і середостіння, у подальшому виконували лапаротомію, накладали гастростому.

При РС черевної частини, що виникає значно рідше, здійснювали лапаротомію, зашивання дефекту з його фундоплікацією за Ніссеном і дренування. Операцію за будь-якої локалізації РС починали 3 ретельної санації та промивання гнійної порожнини, а при необхідності - декортикації легені, і тільки після цього здійснювали маніпуляції на стравоході. Оперативне втручання завершували повторним промиванням гнійної порожнини.

\section{РЕЗУЛЬТАТИ ТА ÏХ ОБГОВОРЕННЯ}

Оперовані 60 хворих. В однієї пацієнтки з лінійним розривом слизової оболонки стравоходу, що виник внаслідок балонної дилатації, проведене консервативне лікування 3 позитивним наслідком.

У хірургів немає єдиної точки 3ору щодо зашивання РС. Так, деякі автори [8] вважають за доцільне накладання первинного шва у строки до 12 год від моменту РС, інші - зашивання РС незалежно від строків перфорації [1, 2, 9]. Деякі автори [3] визнають первинне відновлення стравоходу при його розриві найбільш ефективним методом, що дозволив зменшити летальність до 9,5\%. Наш попередній досвід [5, 6] також підтверджує необхідність обов'язкового накладання первинного шва на стравохід незалежно від строків перфорації. Особливо ця процедура необхідна при РС в нижній третині. Навіть тимчасова ізоляція просвіту стравоходу дає можливість усунути гнійний процес в навколишніх тканинах за умови адекватного дренування порожнини гнійника. Неспроможність первинного шва виникає вже при обмеженні гнійного процесу і зменшенні гнійної порожнини. Подальше проточно-аспіраційне дренування дозволяє досягти загоєння дефекту стравоходу.

3 огляду на можливість виникнення неспроможності первинного шва стравоходу, запропоновані методики тимчасового виключення стравоходу шляхом його лігування вище і нижче зони дефекту синтетичними нитками, що розсмоктуються, типу вікрил, PDS [5-7, 9, 10].

Тимчасова ізоляція стравоходу в зоні розриву особливо актуальна за наявності дефекту в нижній третині, коли рефлюкс шлункового соку спричиняє арозію судин гнійної порожнини, включаючи аорту, з летальним наслідком [6]. Наш досвід показує, що тимчасова ізоляція лінії зашитого дефекту стравоходу доцільна за пізньої госпіталізації пацієнтів, наявності дефекту нижньої третини, коли вірогідність виникнення неспроможності первинного шва дуже висока. За відносно стабільного стану хворих ефективність операції підвищується при здійсненні фундоплікації ураженої зони з використанням обмеженої діафрагмотоміі. Незважаючи на високу травматичність, подібне втручання забезпечує значно кращу герметичність первинного шва й ефективність санації гнійної порожнини.
Значні перспективи в лікуванні РС відкривають мініінвазивні хірургічні технології. У лікуванні РС почали використовувати відеоторакоскопічні $[4,11]$ і відеолапароскопічні [12] методи, включаючи відеолапароскопічну фундоплікацію зони розриву [13].

Одним з напрямків мініінвазивного лікування РС є стентування стравоходу з закриттям зони перфорації $[3,14]$. Перспективним методом лікування РС $є$ ендоскопічне вакуумне дренування дефекту стінки стравоходу [11].

Запропоноване використання поролонового обтуратора просвіту стравоходу, що перекриває зону дефекту його стінки, в поєднанні $з$ активною аспірацією, що забезпечує закриття зони перфорації [11]. Подібне втручання поєднували 3 відеоторакоскопічною санацією і дренуванням гнійної порожнини.

Використання нових технологій відкриває великі перспективи в лікуванні РС, проте, власного досвіду їх використання у нас немає.

Померли 14 (22,9\%) хворих, в тому числі при РС у верхній третині 1 , у середній - 2 (3,2\%), у нижній - 11 (18\%). Основною причиною смерті на тлі пізньої діагностики й лікування була поліорганна недостатність внаслідок сепсису, при РС у нижній третині - арозивна кровотеча з аорти через рефлюкс вмісту шлунка.

Більш високу летальність при РС в нижній третині відзначали й інші автори [2, 3]. Найбільш несприятливий прогноз - при занедбаних формах синдрому Боерхаве [3]. Імовірно, більш низька післяопераційна летальність зумовлена своєчасним радикальним лікуванням хворих, що потребує детального аналізу досвіду цих авторів [1 - 4].

\section{вИсновки}

1. Незважаючи на досягнуті успіхи у лікуванні РС, проблема дуже складна.

2. Більшість хворих вмирають через несвоєчасну діагностику РС і поширення гнійно-септичного процесу.

3. Певні надії на покращання результатів лікування РС пов'язані 3 впровадженням в практику сучасних мініінвазивних хірургічних технологій. 


\section{ЛITEPATYPA/REFERENCES}

1. Makarov AV, Bahyrov MM, Hetman VH, y dr. Likuvannia ushkodzhen stravokhodu. Klinichna khirurhiia. 2002;(5-6):15. [In Ukrainian].

2. Sokolov VV. Diahnostyka ta likuvannia ushkodzhen stravokhodu [thesis]. Kyiv; 2004. 18 c. [In Ukrainian].

3. Biancari F, D'Andrea V, Paone R, et al. Current treatment and outcome of esophageal perforations in adults: systemic review and meta-analysis of 75 studies. World J Surg. 2013;37:1051-9.

4. Cho JS, Kim YD, Kim JW, et al. Thoracoscopic primary esophageal repair in patients with Boerhaave's syndrome. Ann Thorac Surg. 2011;91:1552-5.

5. Martynyuk VA, Shipulin PP, Baydan VI, Baydan VV, Polyak SD, Shevchenko VV. Surgical treatment of esophageal rupture of different localization. Klinichna khirurgiia. 2008;(10):7-9.

6. Martynyuk VA, Shipulin PP, Baydan VI, i dr. Khirurgicheskaya taktika pri lechenii razryvov nizhney treti pishchevoda. Khirurgiya Ukraïni. 2013;(4):52-5. [In Russian].

7. Pogodina AN, Abakumov MM. Mekhanicheskie pronikayushchie povrezhdeniya pishchevoda. Khirurgiya. 1998;(10):20-4. [In Russian].

8. Symbas PN, Hatcher CR, Harlaftis W. Spontaneous rupture of the esophagus. Ann Surg. 1978;187:634-9.
9. Liu HC, Chen $\mathrm{CH}$, Chan ML, et al. Management of esophageal perforations in elderly patients. Intern J Gerontology. 2015;9:107-10.

10. Ostapenko GO, Lizhov EV. Khirurgicheskoe lechenie perforatsiy grudnogo otdela pishchevoda, oslozhnennykh diffuznym gnoynym mediastinitom. Sibirskiy meditsinskiy zhurnal. 2008;(1):43-6. [In Russian].

11. Kulish PA, Popov AYu, Porkhanov VA, i dr. Blizhayshie rezultaty lecheniya bolnykh s pronikayushchimi defektami stenki pishchevoda metodom endoskopicheskogo vakuumnogo drenirovaniya. Innovatsionnaya meditsina Kubani. 2016;(2):28-34. [In Russian].

12. Tolen C, Hendrickx L, Van Hee R. Laparoscopic treatment of Boerhaave's syndrome: a case report and review of the literature. Acta Chir Belg. 2007;107:402-4.

13. Oskretkov VI, Guranov AA, Gankov VA, i dr. Endokhirurgicheskoe lechenie bolnykh $s$ perforatsiey pishchevoda. Meditsina i obrazovanie Sibiri. 2014;(2):1-6. [In Russian].

14. Kotiv BN, Dzidzava IN, Brednev AO, i dr. Minimalno invazivnye metody $v$ lechenii spontannogo razryva pishchevoda. Novosti khirurgii. 2015;(4):467-73. [In Russian]. 